\title{
Productivity and cost of biomass harvesting for energy production in coppice natural stands of Quercus pyrenaica Willd. in central Spain
}

\author{
Ruben Laina, Eduardo Tolosana, Yolanda Ambrosio
}

A B S T R A C T

\begin{abstract}
Biomass growing stocks, harvesting productivity and costs of energy production, were studied in thinnings of Quercus pyrenaica. Eleven forest sites were selected in coppices located in Castilla y Leo' $\mathrm{n}$ (Spain). Three systems were employed for harvesting: a mech-anised whole tree harvesting (WTH) system, which included chipping at landing; a fully mechanised cut-to-length (CTL) harvesting system for firewood; and a semi-mechanised CTL system with manual felling and bunching. Three WTH trials had a hauling off $34.7-44.1$ oven-dried tonnes (odt) ha ${ }^{-1}$. In contrast, only 11.6-30.0 odt ha ${ }^{-1}$ were obtained in the other eight CTL trials. Biomass weight equations for stems and whole trees were fitted. Worker operations were time-studied using software designed by the authors. The WTH system reached maximum productivity rates of 3.9 oven-dried tonnes per productive hour (odt $\mathrm{h}^{-1}$ ) for the felling and bunching operation and $6.9 \mathrm{odt} \mathrm{h}^{-1}$ for the forwarding opera-tion. The mechanised CTL harvesting method achieved a productivity range of $1.3-0.5 \mathrm{odt} \mathrm{h}^{-1}$ for the harvesting operation. Furthermore, the average forwarding produc-tivity was $7.3 \mathrm{odt}$ $\mathrm{h}^{-1}$. Motor-manual felling and crosscutting in the CTL system accom-plished a productivity range of $0.7-1.9$ odt $\mathrm{h}^{-1}$. Manual bunching resulted in similar values. The lowest firewood unit cost for trees with $10 \mathrm{~cm}$ of diameter at breast height (DBH) was $62.0 €$ odt $^{-1}$ using a semi-mechanised CTL system. Under similar conditions, this cost was $85.2 €$ odt $^{-1}$ for the mechanised CTL system. Finally, the cost corresponding to chips at landing from WTH sites (average DBH $=10 \mathrm{~cm}$ ) was $65.3 €$ odt $^{-1}$.
\end{abstract}

\section{Introduction}

The Spanish Renewable Energy Plan (2005-2010) [1] has finished. This plan tried to increase renewable energy (RE) production rate of total primary energy production $\left(4.77 \times 10^{12} \mathrm{MJ}\right)$ from $6.3 \%$ in 2005 to $30 \%$ in 2010 . Bioenergy was an important part of the plan's goal. Currently, there are only $648 \mathrm{MW}$ generating capacity installed [2] in biomass power plants; however, the plan had aimed to reach $1317 \mathrm{MW}$ by 2010. The objective remained unaccomplished despite government subsidies for electricity production from forest residuals $\left(0.11 € \mathrm{kWh}^{-1}\right)$ and from forest woody crops $\left(0.16 € \mathrm{kWh}^{-1}\right)$ [3]. According to the RE National Action Plan 2011-2020 [4], renewable energies accounted for $9.4 \%$ of primary energy consumption in 2010, 132,000 Mtep, whereas the goal for 2020 is $20.1 \%$. Regarding electricity production, RE 
accounted for $24 \%$ of total Spanish electricity (21,410 Mtep) production in 2010, whereas the objective for 2020 is to reach a $36 \%$ contribution. Similarly, biomass and biogas are intended to grow at a yearly rate between $7.0 \%$ and $12.6 \%$ during the period 2009-2020. Measures fostering the energy use of forest and agricultural products or residues, in addition to woody crops, are aimed at producing an additional consumption of $5.5 \times 10^{6}$ tonnes of biomass per year. To achieve this aim would require tremendous efforts to mobilise all biomass sources, including woody biomass. In particular, the government of Castile and León approved a regional bioenergy plan in 2010 [5] with the goal of collecting $1.5 \times 10^{6}$ tonnes of biomass per year from biomass harvested in 60,000 ha of regional forests in the next 10 years. This Plan predicts 1.300 new employs will be generated [5].

Coppice areas of Quercus pyrenaica represent $64 \%$ of the total area covered by this species, which is 659,000 ha in Spain; moreover, half of this total surface lies within Castile and León [6]. In addition, the management of these coppices is one of the greatest problems faced in forestry research in Spain. In the past, the only silvicultural treatment, and forest management, was the traditional firewood harvesting. Stands were divided in parts and each 20-30 years a clear-cutting was performed in each part to obtain wood for combustion or making charcoal. After clear-cutting a subsequent shoot or root regeneration occurred. Over the last 50 years this activity was progressively abandoned because of rural emigration to the cities and the introduction of fuel heating in household [7]. The budget for forest administration is insufficient to perform an alternative forest management in high density coppices needed to avoid diseases, reduce forest fire risk or promote the health and growth of stands. New markets that increase the demand for forest biomass would enhance the development of new forest management systems or, alternatively, would update traditional treatments with new technologies and/or systems.

Here, we present the results of a time study of three different biomass harvesting systems: a mechanised whole tree harvesting (WTH) system followed by chipping at landing; a mechanised cut-to-length (CTL) harvesting system to produce firewood; and a motor-manual option for felling and manual bunching CTL. The hauling off was performed in every case by forest forwarders (Table 1). There are few references about the productivity of forest harvesting in Spain, and none of them focuses on this kind of forest [8-10].

In practice, WTH is a rarely used system for roundwood or biomass harvesting in Spain. However, it is widely used for harvesting biomass from small trees in selective thinning; mainly multi-tree harvesters followed by forwarders are used in Nordic countries [11,12] and North America [13]. In southern European countries, only a few articles in the local literature mention WTH applied to coppices [14]. Spinelli et al. [15] studied WTH followed by forest cable crane hauling off applied to beeches (Fagus sylvatica) with $15-30 \mathrm{~cm}$ of diameter at breast height (DBH). This study was conducted in mountainous stands and compared motor-manual versus mechanised processing. For Quercus or other natural coppices, the application of WTH has not yet been investigated, with some exception, for example a study on Italian Robinia and Platanus spp. with a different typology, i.e., linear coppices [16].

The CTL system is often adopted by local companies in Spain that mainly use short log lengths (2.0-2.5 m) of Eucalyptus pulpwood and young pine artificial stands; however, it is also used for firewood from Quercus or other hardwood forests. However, there are no published local references regarding the application of CTL systems to coppices.

Several articles explore non-conventional harvesting systems for collecting firewood in the mountainous conditions of southern European countries. In northern Italy, the hauling off firewood and the productivity of manual CTL system operations were measured in several silvicultural interventions with different methods [17]: sliding on terrain, using polyethylene chutes, skidding with winch-equipped farm tractors and hauling off with light to medium-sized cable cranes. The costs ranged from 111 to $143 €$ per green tonne.

Gallis [18] summarised the result of hauling off unevenly aged beech stands using mules compared with extracting trees with a mini-skidder ("iron-horse" type). A CTL system was chosen for small diameters from 10 to $20 \mathrm{~cm}$. The results of that study always favoured the use of mules because they

Table 1 - Experimental design. Summary of stands, systems and machinery.

\begin{tabular}{|l|c|c|c|c|}
\hline Sites & Work System & $\begin{array}{c}\text { Felling and } \\
\text { bunching (and also } \\
\text { processing in CTL) }\end{array}$ & Forwarding & Chipping \\
\hline $\begin{array}{l}\text { WTH1 } \\
\text { WTH2 } \\
\text { WTH3 }\end{array}$ & $\begin{array}{c}\text { Whole tree } \\
\text { harvesting system }\end{array}$ & $\begin{array}{c}\text { Timberjack 1070 } \\
\text { harvesting head } 745 \\
\text { Accumulating arms }\end{array}$ & $\begin{array}{c}\text { Timberjack } \\
1410 \\
\text { forwarder }\end{array}$ & $\begin{array}{c}\text { Pezzolato } \\
900 / 1000 \\
\text { truck mounted } \\
\text { drum chipper }\end{array}$ \\
\hline $\begin{array}{l}\text { CTL1 } \\
\text { CTL2 }\end{array}$ & $\begin{array}{c}\text { Fully mechanised } \\
\text { CTL3 }\end{array}$ & $\begin{array}{c}\text { Timberjack 1270 C } \\
\text { cut-to-length system }\end{array}$ & $\begin{array}{c}\text { Valmet 910 } \\
\text { forest } \\
\text { forwarder }\end{array}$ & $\begin{array}{c}\text { No chipping } \\
\text { (firewood) }\end{array}$ \\
\hline $\begin{array}{l}\text { CTL4 } \\
\text { CTL6 } \\
\text { CTL7 }\end{array}$ & $\begin{array}{c}\text { Motor-manual felling } \\
\text { and processing cut- } \\
\text { CTL8 }\end{array}$ & $\begin{array}{c}\text { to-length system } \\
\text { Husqvarna 359 and }\end{array}$ & $\begin{array}{c}\text { Valmet } \\
860.3 \text { forest } \\
\text { forwarder }\end{array}$ & $\begin{array}{c}\text { No chipping } \\
\text { (firewood) }\end{array}$ \\
\hline
\end{tabular}


cost an average of $26 \%$ less. The productivity ratio between mule and iron horse was $3.5-2.5$ odt $\mathrm{h}^{-1}$. Dissimilar results were found by Magagnotti et al [19]. They reported more costeffectiveness using tractor for logging instead of mule pack in Turkey oak stands.

In Italy, cable yarding have been used to haul firewood off from coppices of Quercus cerris, oak, holm oak and beech stands $[20,21]$. The productivity was greater than what could be considered, varied between 1.4 and $2.6 \mathrm{~m}^{3}$ per scheduled time. This logging system reached competitive operating cost compared to other logging system [21].

To support the increasing wood energy production and considering the scarcity of scientific studies conducted locally, this study had three main goals:

- Estimate the biomass growing stock of Q. pyrenaica coppices by fitting aboveground biomass equations.

- Set up a productivity reference for biomass of whole tree harvesting systems followed by chipping at landing and cutto-length harvesting systems. Similarly, we aimed to develop, when possible, productivity equations to evaluate the effects of the main explanatory factors (e.g., tree size and forwarding distance).

- Evaluate chip supply costs, including transport costs, indirect costs and contractor profits, under the studied conditions and the influence of the main identified variables.

\section{Materials and methods}

This study was focused on heavy thinning to transform coppice into coppice with standards towards its conversion to high forest. The thinning type was from low, eliminating small tress, trees with badly shaped crowns, twisted stems and disease diseases tree. This treatment applied to the Quercus pyrenaica coppice was experimented by Cañellas et al. [22]. Eleven Q. pyrenaica oak stands were selected in the Castilla y León region; three of them were used to assess the WTH system (replications WTH1, WTH2 and WTH3) and were located in the vicinity of La Ercina Municipality (Leon Province). The other eight were used to evaluate the CTL harvesting system (replications: mechanised felling CTL1-CTL4, manual felling CTL5-CTL8) and were located near Astorga (Leon Province).

At each stand, three permanent plots of $400 \mathrm{~m}^{2}$ each were inventoried by recording the $\mathrm{DBH}$ and total height of every tree, before and after felling. In addition, the biomass of random samples of 21 trees ranged from 2.5 to $25 \mathrm{~cm}$ of DBH was weighed separately by components (stem up to top diameter $7 \mathrm{~cm}$, top and branches with $>7 \mathrm{~cm}$ diameter, branches $2-7 \mathrm{~cm}$, branches $<2 \mathrm{~cm}$ and leaves). A roman scale, tested previously in laboratory, was used. Total number of trees sampled was 21. For each sample tree in each size category, according to Ruiz-Peinado et al. [23], a 500-g sample was collected to measure moisture in the laboratory. These samples were oven-dried to constant weight at $105^{\circ} \mathrm{C}$.

These weight data were used for fitting an allometric equation that related weight and DBH. This biomass model is of the form Aboveground Biomass $(\mathrm{kg})=C F \cdot a \cdot\left[D B H(\mathrm{~cm})^{b}\right.$, where $a$ and $b$ are parameters, $C F$ is bias correction $C F=\exp$ (Mean Squared Error/2) and DBH is diameter at breast height $(\mathrm{cm})$. is the one most commonly used in the scientific literature [24,25].

Green and dried weight per hectare were determined as a sum of the diameter class values corresponding to the product of the tree number per hectare times diameter classes weighting. Total Biomass per ha $=\sum$ (Aboveground biomass $(\mathrm{kg})_{\mathrm{i}} \cdot$ No trees per ha $\mathrm{i}_{\mathrm{i}} / 1000, \mathrm{i}=$ diameter class.

The machines used for different operations are shown in Table 1. Figs. 1 and 2 illustrate the studied forest harvesting systems.

A time study requires the division of the studied operations into different working elements, and the measurement of time and production during several work cycles should be assessed. Two recording methods were employed for the time study of different machines and operations, according with Magagnotti \& Spinelli [26]:

- For the continuous timing method, a Psion WorkAbout ${ }^{\circledR}$ hand-held data recorder with purpose-designed software called Kronos 3.0 ${ }^{\circledR}$ was used [27]. This was the method chosen to follow felling and bunching with harvesters and hauling off with forwarders. The abovementioned software allows recording the time spent in each elemental operation and different production parameters, such as distances, number of trees and diameter classes. This software saves time data in an MS Access ${ }^{\circledR}$ database.

- A work sampling method was chosen for the chipping operation. A chronometer beeped every $60 \mathrm{~s}$ and the performed work phase was marked in a previously designed form.

Time studies are always combined with productivity control. The production was measured in different ways depending on the type of operation: for operations with trees or logs, the trees or logs were counted; for operations with tractor loads, the number of trees or logs in each load or the bulk chip volume was registered. In any case, the time dedicated to a certain operation was related to the biomass weight

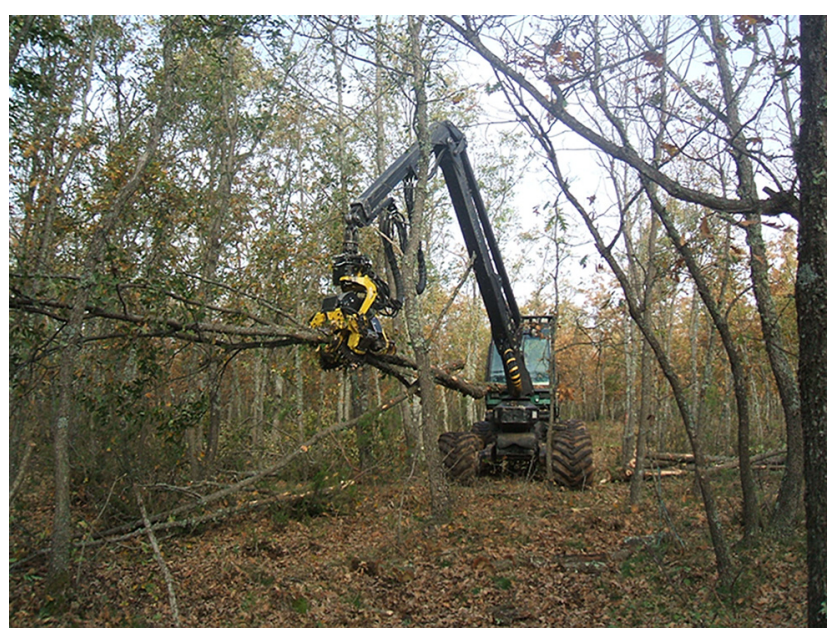

Fig. 1 - Multi-tree forest harvesting felling a Quercus coppice stand (WTH3). 


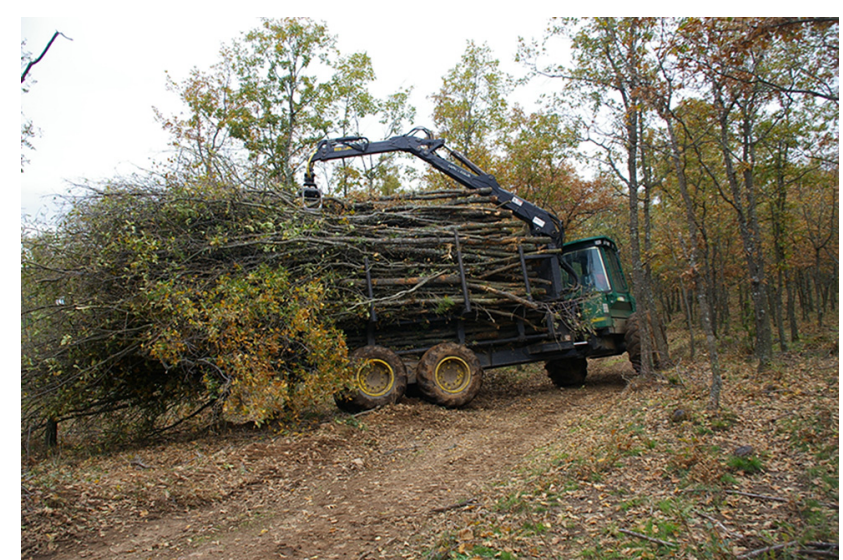

Fig. 2 - Forest forwarder hauling off whole trees from coppice thinning (WTH1).

produced. When the estimation was indirect, for example, through the number of trees or logs and a weight table, it was necessary to measure the biomass percentage left in the terrain, by weighing the biomass left in 10-m radius circular plots inside the permanent plots defined before.

Coefficients that related work time to productive working time or time spent at each work site were calculated. Where the continuous method of time study was chosen, predictive equations were fitted with standard statistics software (Statgraphics ${ }^{\circledR}$ and SPSS ${ }^{\circledR}$ ).

The hourly costs of machines and operators were estimated according to the proposed harmonization by Ackerman et al [28]. Once the work time was defined as the common basis for calculations, hourly costs and productivity were expressed as a function of work time. Therefore, it was possible to estimate direct costs on a production basis (green tonne, odt, $\mathrm{m}^{3}$ loose volume, etc.).

\section{Results and discussion}

\subsection{Forest inventories and weight equations}

WTH was tested in the described three different stands with an average $\mathrm{DBH}$ ranged from 9.1 to $10.6 \mathrm{~cm}$. CTL stands registered smaller average $\mathrm{DBH}$, between 5.8 and $10.5 \mathrm{~cm}$. Top height values were greater in WTH trials, with the exception of WTH1 with a value of $6.2 \mathrm{~m}$. All trials had high tree density, with a maximum of 8700 trees ha ${ }^{-1}$ (CTL4) and a minimum of 1825 trees ha $^{-1}$ (CTL6).

The main results of the forest inventories are summarised in Table 2, which includes characteristics of the studied stands and silvicultural treatments.

The thinning intensity is considered heavy when the extracted basal area was greater than $50 \%$ of the initial area [22]. If a strip road area was not considered, then the extracted basal area was lower, close to $40 \%$ of the initial value on average. Heavy fellings have the advantage of decreasing operating and management costs, increasing the rotation time for the next thinning and increasing the growing rate during the following years. In contrast, a stronger sprouting could occur, however Cañellas et al. [22] did not find any relation between thinning intensity $(15-50 \%$ of basal area removal) and epicormic sprouts.

The maximum removal, 44.1 odt ha ${ }^{-1}$, occurred in WTH1, whereas the minimum removal was 11.6 odt ha ${ }^{-1}$ in CTL5. In the CTL system, leaves and branches were not harvested; therefore, the WTH system had higher extracted biomass, between 93 and 115\%, than that of the CTL system with the same thinning intensity and average DBH That was between 11.1 and 35.9 odt per ha of difference.

Leaves accounted for $6 \%$ of aboveground weight, Fig. 3 , and contained higher nutrient concentrations than that of the stems [29]. Q. pyrenaica forests usually grow in acid soils. These soils can be poor in Ca. Thus, according to a study on aboveground Ca content, Ca removal could range between 47 and $194 \mathrm{~kg} \mathrm{ha}^{-1}$ [30]. To reduce the nutrient depletion in WTH systems, harvesting in the winter could reduce the nutrient extraction to $12-15 \mathrm{~kg} \mathrm{ha}^{-1}$, if $\mathrm{Ca}$ is limited. In addition, ashes from biomass combustion can be used as fertiliser [31,32]. If ashes were returned to forest stands, almost $20 \%$ of the removed Ca would return to the soil.

The biomass humidity of different parts of Q. pyrenaica was measured. The dry-basis moisture content ranged from $66 \%$ for stems and branches to $114 \%$ for leaves. The average moisture content of aboveground biomass was $69 \%$. Hence, $Q$. pyrenaica biomass had low moisture, which improves its quality as fuel.

Another relevant result of the laboratory analysis was the lower heating values, which were $18.98 \mathrm{MJ} \mathrm{kg}^{-1}$ (dry basis) and $10.93 \mathrm{MJ} \mathrm{kg}^{-1}$ (green basis).

Allometric regressions were fitted using weight data from sample trees, and several tables were obtained. They were compared with other local tables for the same species [33], and the differences were lower than $9 \%$. DBH-based weight tables are presented in Fig. 4 together with the ratio of aboveground $\cdot$ stem $^{-1}$ oven-dried biomass as a function of $\mathrm{DBH}$.

\subsection{Time study results}

The productivity of each machine and worker was expressed in oven-dried weight per productive hour (odt $\mathrm{h}^{-1}$ ). Thus, the time spent in maintenance, repositioning and planning was not included. The main results are summarised in Table 3.

\subsubsection{Felling and bunching productivity}

The highest felling and bunching productivity was reached in WTH trials, where it varied between 2.8 and 3.9 odt $\mathrm{h}^{-1}$. In mechanised CTL trials, the productivity ranged between 0.5 and 1.0 odt $\mathrm{h}^{-1}$. These differences could be explained by the shorter time needed per tree in the WTH trials and the lower biomass per tree in the CTL trials.

A comparative ANOVA analysis showed a statistically significant difference in time per tree between the WTH and CTL trials. The average efficiency for WTH was $24 \mathrm{~s}$ tree ${ }^{-1}$, whereas it was 26 s tree $^{-1}$ in CTL (9\% difference). This difference was greater than the one registered by Kärhä [11], which was $6 \%$ for trees with $11 \mathrm{~cm} \mathrm{DBH}$ and a removal of 1044 trees ha $^{-1}$. However, because the crosscutting time was $35 \%$ of the productive time, a greater difference in system efficiency was 
Table 2 - Stand description of experimental sites.

\begin{tabular}{|c|c|c|c|c|c|c|c|c|c|c|c|}
\hline & \multicolumn{3}{|c|}{$\begin{array}{l}\text { Whole tree } \\
\text { harvesting system }\end{array}$} & \multicolumn{4}{|c|}{$\begin{array}{l}\text { Cut-to-length } \\
\text { system } \\
\text { (mechanised) }\end{array}$} & \multicolumn{4}{|c|}{$\begin{array}{l}\text { Cut-to-length } \\
\text { system (manual } \\
\text { felling, MF) }\end{array}$} \\
\hline & WTH1 & WTH2 & WTH3 & $\begin{array}{c}\mathrm{CTL} \\
1 \\
\end{array}$ & $\begin{array}{c}\mathrm{CTL} \\
2 \\
\end{array}$ & $\begin{array}{c}\text { CTL } \\
3 \\
\end{array}$ & $\begin{array}{c}\text { CTL } \\
4 \\
\end{array}$ & \begin{tabular}{|c|}
$\mathrm{CTL}$ \\
5 \\
\end{tabular} & $\begin{array}{c}\text { CTL } \\
6 \\
\end{array}$ & $\begin{array}{c}\text { CTL } \\
7 \\
\end{array}$ & $\begin{array}{c}\mathrm{CTL} \\
8 \\
\end{array}$ \\
\hline Slope (\%) & 10 & 14.5 & 1 & 9 & 24 & 15 & 3 & 9 & 24 & 15 & 3 \\
\hline $\begin{array}{c}\text { Average } \\
\mathrm{DBH}(\mathrm{cm})\end{array}$ & 10.3 & 10.6 & 9.1 & 9.5 & 7.8 & 7.7 & 5.8 & 7.6 & 10.5 & 7.4 & 6.9 \\
\hline $\begin{array}{c}\text { Top height } \\
(\mathrm{m})\end{array}$ & 6.2 & 10.8 & 9.9 & 8.9 & 8.5 & 8.4 & 8.6 & 8.9 & 8.5 & 8.4 & 8.6 \\
\hline $\begin{array}{c}\text { Initial } \\
\text { density } \\
\left.\text { (trees ha }^{-1}\right) \\
\end{array}$ & 2570 & 3281 & 3700 & 3429 & 4263 & 4753 & 8376 & 4166 & 1825 & 6567 & $\begin{array}{c}870 \\
0\end{array}$ \\
\hline $\begin{array}{c}\text { Extracted } \\
\text { density } \\
\text { (trees ha }^{-1} \text { ) }\end{array}$ & 1685 & 2075 & 2462 & 2419 & 3066 & 2227 & 5916 & 1833 & 975 & 4699 & $\begin{array}{c}690 \\
0\end{array}$ \\
\hline $\begin{array}{c}\text { Initial basal } \\
\text { area }\left(\mathrm{m}^{2}\right. \\
\left.\mathrm{ha}^{-1}\right)\end{array}$ & 21.5 & 28.7 & 24 & 20.5 & 20.2 & 18.9 & 22.5 & 20.1 & 17.3 & 31.7 & 32.3 \\
\hline $\begin{array}{c}\% \\
\text { extracted } \\
\text { BA }\end{array}$ & 49 & 51.7 & 49.8 & 64.1 & 53.5 & 68.6 & 55.2 & 52.6 & 52.7 & 67.4 & 62.8 \\
\hline $\begin{array}{c}\text { Extracted } \\
\text { biomass } \\
(\text { odt ha-1) }\end{array}$ & 34.7 & 44.1 & 36.4 & 22.8 & 19.3 & 13.5 & 15.1 & 11.6 & 16.6 & 31.3 & 30.0 \\
\hline
\end{tabular}

expected. Other variables also affected efficiency; for example, worker ability caused a $40 \%$ difference with the same machine and forest (Ryÿnänen and Rönkkö, cited by Ovaskainen [34]). Spinelli et al. [15] registered an efficiency ranging from 21 to $24 \mathrm{~s}^{-1} \mathrm{e}^{-1}$ for Carpinus, Quercus and Tilia natural coppices with $10.2 \mathrm{~cm} \mathrm{DBH}$ and a removal of 1368 trees ha ${ }^{-1}$. Furthermore, these authors recorded an efficiency

\section{Green weight distribution of avobe - ground biomass. Quercus pyrenaica Willd dbh=12 cm.}

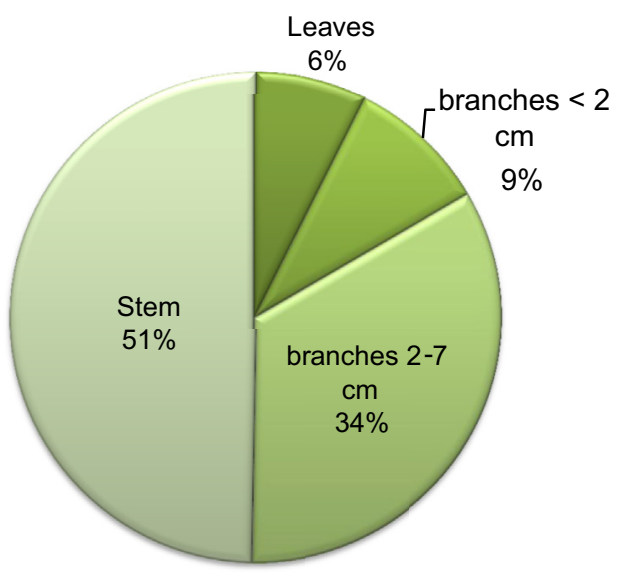

Fig. 3 - Green weight distribution of avobe-ground biomass. of $14 \mathrm{~s}^{\text {tree }} \mathrm{e}^{-1}$ in a Platanus plantation with $6.9 \mathrm{~cm} \mathrm{DBH}$ and a removal of 2368 trees $\mathrm{ha}^{-1}$.

In motor-manual felling CTL stands, two different chainsaw operators were time-studied in 4 strata. Even

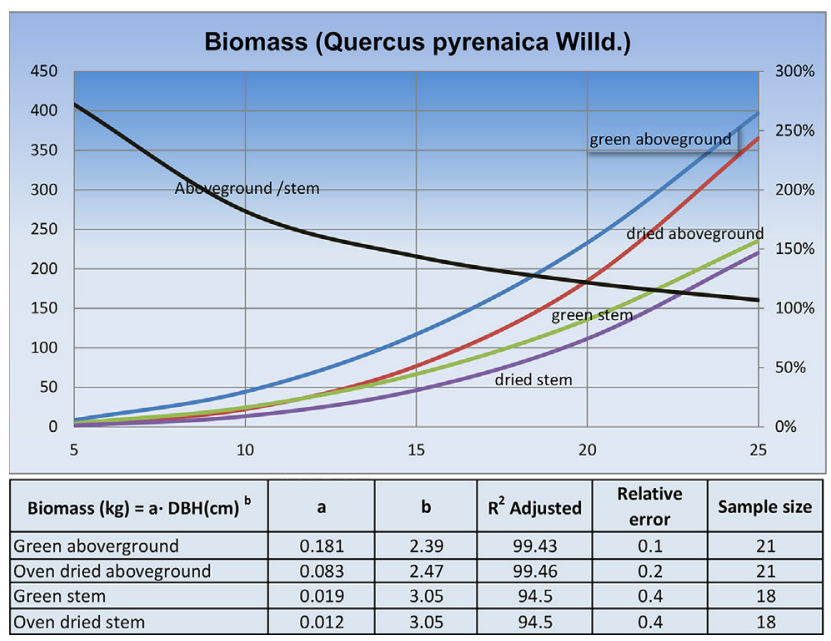

Fig. 4 - DBH and dried/green aboveground and stem biomass curves in Quercus pyrenaica Willd. The decreasing blue curve represents the ratio of aboveground biomass to stem biomass (right scale). (For interpretation of the references to colour in this figure legend, the reader is referred to the web version of this article.) 


\begin{tabular}{|c|c|c|c|c|c|}
\hline & & \multicolumn{4}{|c|}{ Productivity (odt productive hour ${ }^{-1}$ ) } \\
\hline & System & Felling & Bunching & Forwarding & Chipping \\
\hline \multirow{7}{*}{ Mechanised } & WTH1 & \multicolumn{2}{|r|}{2.8} & 5.6 & 4.7 \\
\hline & WTH2 & \multicolumn{2}{|r|}{3.9} & 5.6 & 6.1 \\
\hline & WTH3 & \multicolumn{2}{|r|}{2.9} & 6.9 & 5.2 \\
\hline & CTL1 & \multicolumn{2}{|r|}{1.3} & 6.6 & - \\
\hline & CTL2 & \multicolumn{2}{|r|}{1.0} & 5.9 & - \\
\hline & CTL3 & \multicolumn{2}{|r|}{1.0} & 6.8 & - \\
\hline & CTL4 & \multicolumn{2}{|r|}{0.5} & 5.9 & - \\
\hline \multirow{4}{*}{$\begin{array}{l}\text { Motor-manual } \\
\text { felling and } \\
\text { manual } \\
\text { bunching }\end{array}$} & CTL5 MF & 1.4 & 1.0 & 6.6 & - \\
\hline & CTL6 MF & 2.1 & 0.9 & 5.9 & - \\
\hline & CTL7 MF & 1 & 0.8 & 5.5 & - \\
\hline & CTL8 MF & 0.7 & 0.9 & 4.9 & - \\
\hline
\end{tabular}

though there were no significant differences in efficiency between the two operators, there were significant differences among stands. CTL8 was the trial with the lowest time per tree $\left(14.9 \mathrm{~s} \cdot\right.$ tree $\left.^{-1}\right)$, whereas the greatest time per tree was reached in CTL6 (30.0 s tree ${ }^{-1}$ ). Bunching was performed by another worker with an average productivity of 0.9 odt $\mathrm{h}^{-1}$.

Another ANOVA analysis was performed to compare the efficiency between mechanised and manual felling as well as bunching in CTL stands. In CTL4 and CTL8, the trials with minimum DBH and maximum removal density, mechanised felling and bunching was $7.2 \mathrm{~s}^{-1} \mathrm{tree}^{-1}$ faster than that of the manual method. In contrast, for CTL1 and CTL6, the trials with maximum DBH and minimum removal density, was $8.1 \mathrm{~s}$ tree $^{-1}$. These results indicate that with increasing tree size, there was an increase in the difference between manual and mechanised felling and bunching efficiencies.

Different models were tested to obtain regression residuals that were as symmetrical as possible and to achieve the best determination coefficients for the final equations. The independent variables for felling were $\mathrm{DBH}$ and number of trees cycle $^{-1}$, whereas in the forwarding function, the main explanatory factor was the distance to landing. Fig. 6 shows

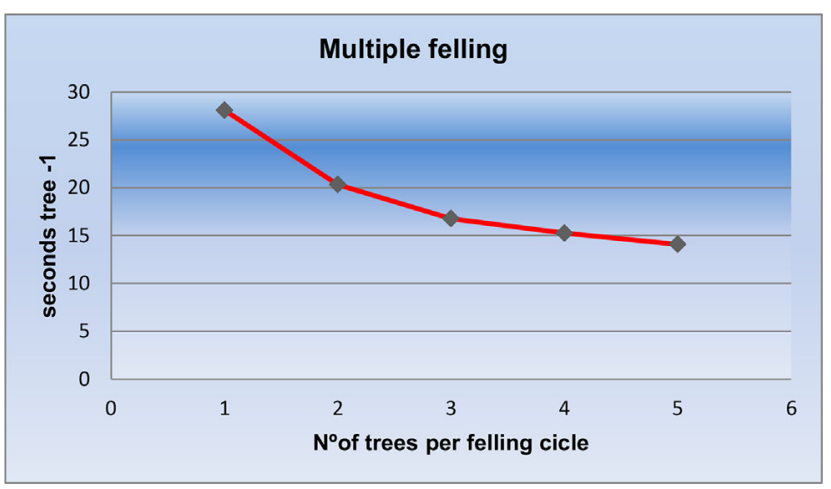

Fig. 5 - Efficiency per tree with accumulating head processor. the results for mechanised felling and, in the case of CTL, processing.

One of the most important explanatory factors for the productivity of felling and bunching (as well as processing in CTL) was average DBH $[11,35]$. A significant relationship between time per tree and DBH was found in the CTL equations.

In the WTH trials, a significant relationship between the number of trees per multi-felling cycle and productivity time was found. Grouping several felling with accumulating grip decreased the time per tree, as shown in Fig. 5. Sixty-six percent of felling operations were multiple, which resulted in an increased efficiency of $5.9 \mathrm{~s} \cdot$ tree $^{-1}$ if time consumption was compared with single-tree time consumption. This timesaving efficiency improved the productivity by $21 \%$.

The adjusted $R^{2}$ values of the global equations were lower than those obtained by Nakagawa [35] for harvesting

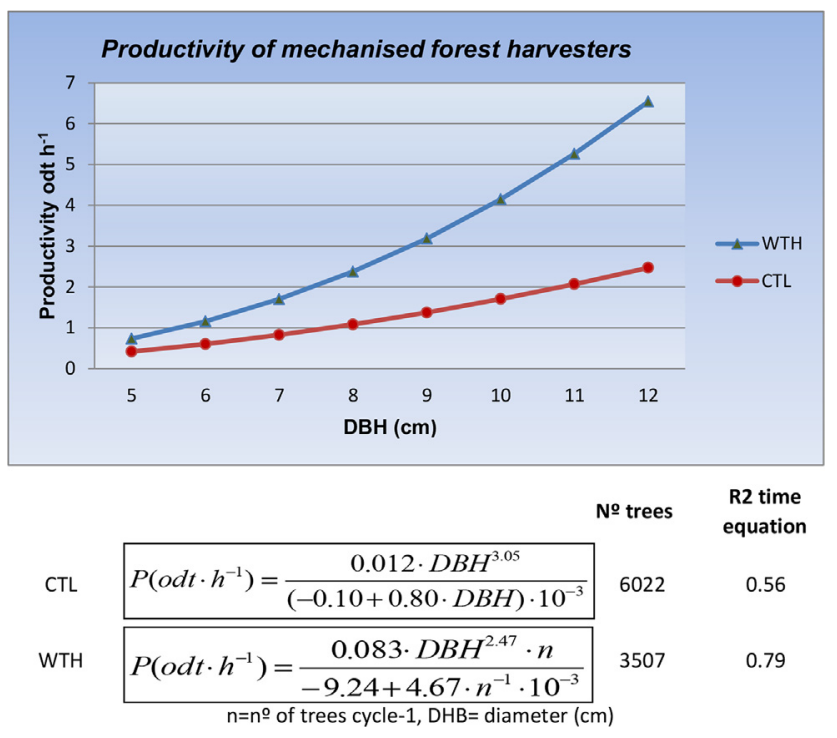

Fig. 6 - Effect of DBH variation in mechanised felling and bunching productivity. 
operations and higher than 3 of the four obtained by Kärhä [11]. Our adjusted $R^{2}$ values are similar to the adjusted $R^{2}$ values obtained by Spinelli [15] for a time equation fitted to harvest data for Betula sp. and Platanus sp.

If the global time equation for mechanised felling and bunching was transformed into a productivity equation using the dry aboveground biomass function from Fig. 4, then the difference between trials could be explained. The productivity equation is represented in Fig. 6.

In the motor-manual CTL trials, no significant differences in efficiency were found between the two chainsaw operators. However, for each operator, there were significant differences among stands. As in the mechanised trials, the highest average efficiency was registered in CTL4 (14.9 s.tree ${ }^{-1}$ ), whereas the lowest average time per tree was reached in CTL2 $\left(28.8 \mathrm{~s} \cdot\right.$ tree $\left.^{-1}\right)$. Bunching of logs was performed by another worker with an average productivity of 0.9 odt $\mathrm{h}^{-1}$, which translated to $12 \mathrm{~s} \cdot$ tree $^{-1}$.

\subsubsection{Forwarding productivity}

The main variable that influenced the hauling productivity was the distance between bunching and landing sites ([12,37]). The average productivity rates were 6.3 odt $\mathrm{h}^{-1}$ with $170 \mathrm{~m}$ of forwarding distance for WTH and 7.3 odt $^{-1}$ with $510 \mathrm{~m}$ of forwarding distance for CTL. Kärhä [12], recorded a productivity of 10.0 solid $\mathrm{m}^{3} \mathrm{~h}^{-1}$ for whole-tree forwarding for a distance of $250 \mathrm{~m}$. If a conversion factor of 0.6 odt per solid $\mathrm{m}^{3}$ is considered [37], that productivity was 6 odt $\mathrm{h}^{-1}$

For the WTH strata, the forwarding productivity is graphically depicted as a function of average hauling distance in Fig. 7.

The narrow range of forwarding distances did not allow fitting any equations relating forwarding productivities to forwarding distances in CTL harvesting systems.

The loading operation was compared between systems. This operation occupied approximately half of the productive time. Even when the difference among loading times was not statistically significant, there were significant differences between the two methods if production was taken into account. CTL achieved a 15 odt $\mathrm{h}^{-1}$ average loading productivity, whereas WTH reached an average of only 9.6 odt $\mathrm{h}^{-1}$; this difference is due to the higher weight per load. This result was related to the shape of piece [38].

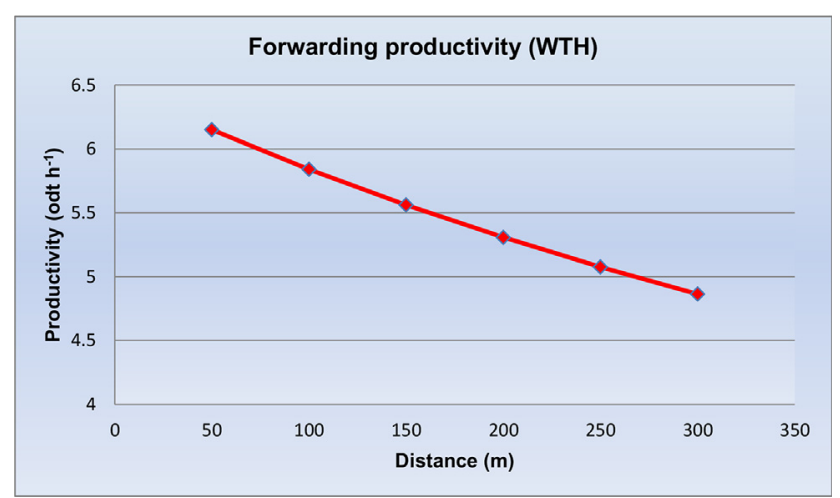

Fig. 7 - WTH hauling off productivity with respect to hauling distance.
In the CTL strata, a significant difference of 1.5 odt $\mathrm{h}^{-1}$ (14\%) was found in hauling off productivity depending on the felling method, processing and bunching. A higher productivity was obtained for the fully mechanised CTL system in contrast to manual felling. A detailed analysis indicated that the loading operation was the most important time element affecting productivity. The average time per load was $1804 \mathrm{~s}$ in motor-manual operations versus only $1499 \mathrm{~s}$ in mechanised operations. This difference is lower than the one reported by Laitila [36], who registered a time consumption for loading in manual cutting nearly 2.5 times higher than that for fully mechanised operations.

In WTH sites, chipping was performed at landing by a drum chipper. This truck-mounted machine had $310 \mathrm{~kW}$ of power. An average productivity of $5.3 \mathrm{odt} \mathrm{h}^{-1}$ was reached, equivalent to 22.1 loose $\mathrm{m}^{3} \mathrm{~h}^{-1}$. The relocation of machines at landing accounted for $5 \%$ of working time. Finally, an important maintenance operation, knife substitution, accounted for $11 \%$ of working time.

\subsubsection{Cost estimation}

The hourly cost obtained for forest harvesters was $75 €$ work $\mathrm{h}^{-1}$; the estimated costs were $61 €$ work $\mathrm{h}^{-1}$ for forwarders, $96 €$ work $\mathrm{h}^{-1}$ for chippers, $22 €$ work $\mathrm{h}^{-1}$ for each chainsaw operator and $18 €$ work $\mathrm{h}^{-1}$ for the bunching operator. The following utilization ratios were assumed to make the unit cost estimations: 0.75 for harvesters, 0.85 for forwarders and 0.70 for manual felling and bunching [39].

For the felling and bunching operations in WTH systems, the unit cost $\cdot \mathrm{odt}^{-1}$ is represented as a function of the number of trees cycle ${ }^{-1}$ and DBH in Fig. 8.

In Fig. 9, the direct unit costs of WTH felling, bunching, forwarding and chipping were compared with those for felling, processing and forwarding logs in both CTL options.

Mechanised felling and bunching were the most expensive operations. The unit cost of these operations ranged between 1.7-fold and 20-fold compared with the forwarding unit cost in the mechanised CTL system. This ratio was lower in the semimechanised CTL system, ranging between 2.8-fold and 4.3fold.

For the same average DBH, the unit cost for biomass harvesting was lower for the WTH system than for the CTL system. The lowest unit cost in mechanised CTL was $12.6 €$ odt $^{-1}$ more expensive than the cheapest biomass from the WTH trials. In stands with similar average $\mathrm{DBH}$ and tree density

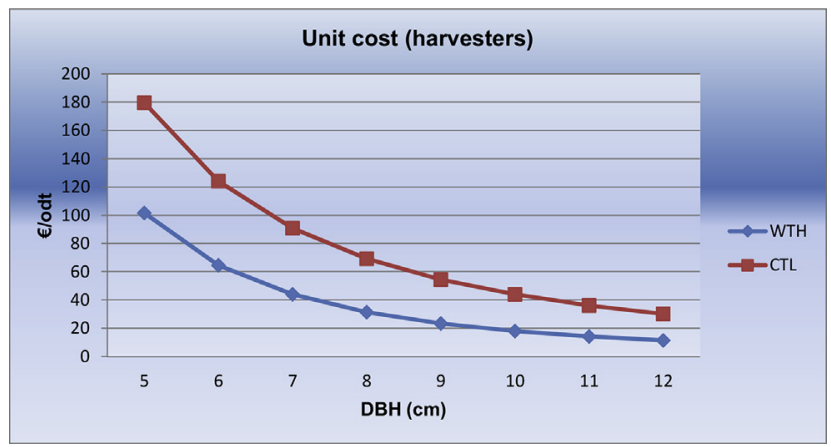

Fig. 8 - Unit cost of harvester operations in mechanised systems. 


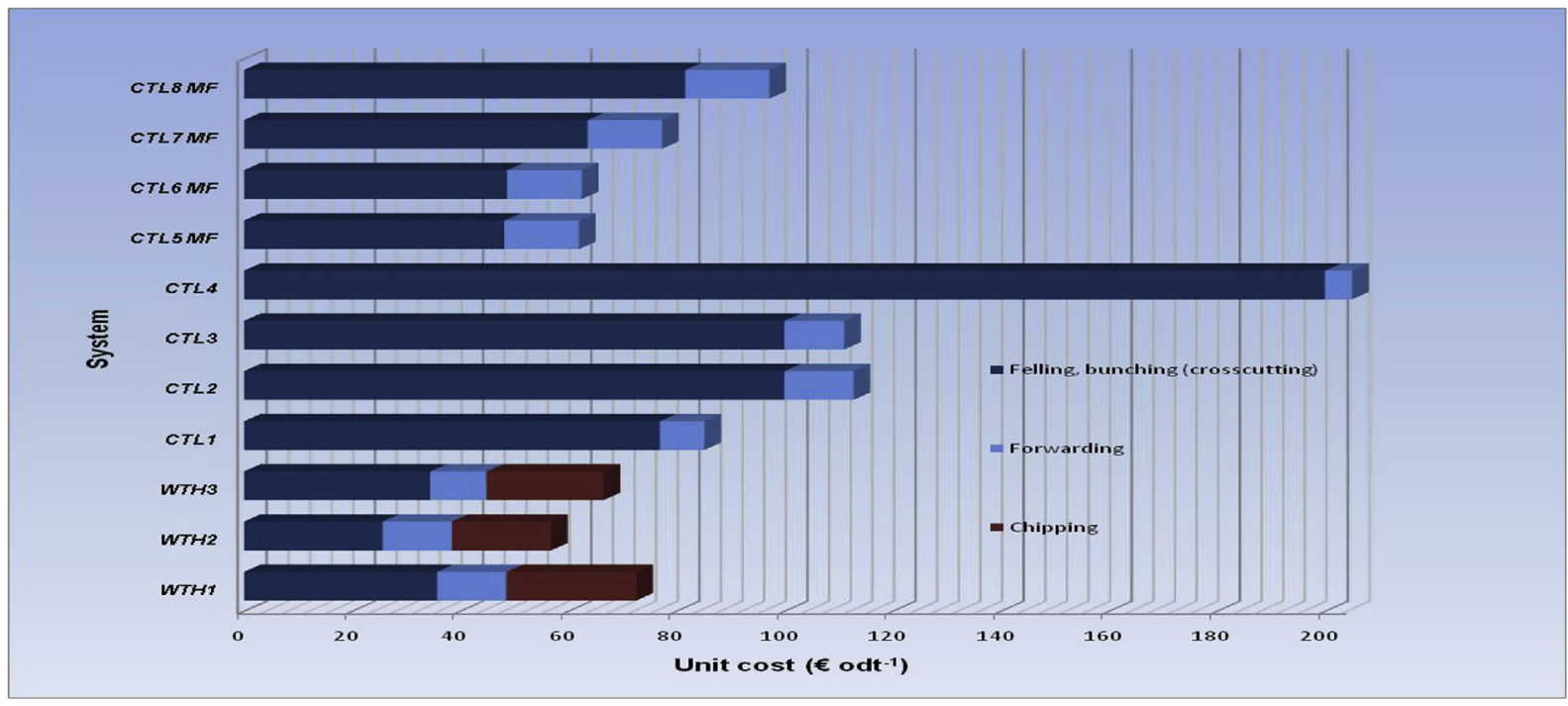

Fig. 9 - Unit cost for each system.

removal, the difference in unit cost between CTL and WTH was $23.5 € \mathrm{odt}^{-1}$. Furthermore, in the CTL system, when the average DBH declined to $5 \mathrm{~cm}$ in CTL4, the unit cost strongly increased to more than $200 €$ odt $^{-1}$.

In the CTL strata, manual felling and bunching produced a lower unit cost.odt ${ }^{-1}$ than the mechanised system for the same average DBH and tree density extracted. The unit cost in the CTL strata varied between 48 and $82 €$ odt $^{-1}$. For trees with an average $\mathrm{DBH}$ of $10 \mathrm{~cm}$, the biomass unit cost of the mechanised felling and bunching CTL harvesting system was around $30 €$ higher than that of the CTL system with motormanual felling.

Forwarding costs were similar between WTH and CTL and ranged between a minimum value of $8.5 € \mathrm{odt}^{-1}$ in WTH3 and a maximum of $15.6 €$ odt $^{-1}$ in CTL4 (manual felling). Interestingly, manual felling increased the forwarding unit cost by $10 €$ trip $^{-1}$ on average.

\section{Conclusions}

The rate of removal of biomass from heavy thinning in dense Q. pyrenaica Spanish coppices has ranged from 11.6 to 44.1 odt ha ${ }^{-1}$. In every harvesting system, the initial operations (felling and bunching in the WTH system, and crosscutting, delimbing and topping in the CTL system) are the least productive and the most expensive. In the WTH system accumulating arms increased the productivity by more than $20 \%$. The CTL system was less productive in stands with similar DBH. With mechanised felling, processing and bunching, the productivity was 1.3 odt $h^{-1}$, whereas with motor-manual felling and processing, the productivity reached 1.9 odt $\mathrm{h}^{-1}$ (combined with a manual bunching productivity of 0.8 odt $\mathrm{h}^{-1}$ ). Moreover, the main productivity stand factor was tree size (DBH).

Forwarding was more productive in the CTL trials than in the WTH trials; however, in both systems, a similar amount of time was spent for work cycle phases. In the CTL trials, forwarding firewood after fully mechanised felling, processing and bunching was significantly more productive $\left(1.5\right.$ odt $\mathrm{h}^{-1}$ greater) than forwarding it after semi-mechanised harvesting.

In the CTL sites, motor-manual felling, processing and bunching were more cost-efficient than the fully mechanised option in the studied stands. When the average $\mathrm{DBH}$ decreased to $5.5 \mathrm{~cm}$, the unit cost increased to $208.5 €$ odt $^{-1}$ for the mechanised method or $97.2 €$ odt $^{-1}$ for the chainsaw felling method. This difference decreased with average DBH increasing. However felling mechanised improve ergonomic and safety conditions compare to using chainsaw.

WTH of Q. pyrenaica coppices with an average DBH of $10 \mathrm{~cm}$ produced chips with a direct unit cost at landing of $65.3 €$ odt $^{-1}$. This cost was sensitive to $\mathrm{DBH}$ variation. The produced chips had $40 \%$ moisture (humid basis), $10.97 \mathrm{MJ} \mathrm{kg}^{-1}$ as the net heating value, and a density of $403 \mathrm{~kg}$ loose $\mathrm{m}^{-3}$.

\section{Acknowledgements}

We are indebted to the Foundation for the Promotion of Forestry and Forest Industry (CESEFOR) in Castile and León Region (Spain), which funded this applied research and coordinated the field experiments. Likewise, the Regional Forest Service of the Castile and León region supported this research project.

\section{R E F E R E N C E S}

[1] Gobierno de España. Plan de Energías Renovables en España 2005-2010. PER 2005-2010, 2005. p. 1-352.

[2] Dirección de Energía Eléctrica. Evolución histórica mensual de la potencia instalada. Información estadística sobre las ventas de Energía del Régimen Especial 20102011.

[3] Gobierno de España. Real Decreto 661/2007 por el que se regula la actividad de producción de Energía Eléctrica en Régimen Especial. B.O.E. 2007;126:22846-86. 
[4] Gobierno de España. Plan de Acción Nacional de Energías Renovables de España 2011-2020 2010. p. 1-173.

[5] Junta de Castilla y León. Plan Regional de ámbito sectorial de la bioenergía de Castilla y León 2011. BOCyL no. 17.

[6] Junta de Castilla y León. Castilla y León crece con el bosque 2005. p. 48.

[7] Adame P, Canellas I, Roig S, Del Rio M. Modelling dominant height growth and site index curves for rebollo oak (Quercus pyrenaica Willd.). Ann For Sci 2006;63:929-40.

[8] Canga E, Prada M, Majada J. Modelización de la biomasa arbórea y evaluación de rendimientos y costes en una clara de Pinus pinaster para la obtención de biomasa en Asturias. $5^{\circ}$ Congreso Forestal Español 2009. p. 2-16.

[9] Canga E, Vivas A, Sánchez S. Estudio comparativo de dos empacadoras de residuos forestales en el norte de España. Progreso Forestal 2009;19:36-43.

[10] Sanz Infante F, Piñeiro Veiras G. Aprovechamiento de la biomasa forestal producida por la cadena monte-industria. Parte I. Revista CIS Madera 2003:6-25.

[11] Kärhä K. Integrated harvesting of energy wood and pulpwood in first thinnings using the two-pile cutting method. Biomass Bioenerg 2011;35:3397-403.

[12] Karhä K. Whole-tree harvesting in young stands in Finland. For Stud 2006;45:118-34.

[13] Adebayo A, Han H, Johnson L. Productivity and cost of cut-tolength and whole-tree harvesting in a mixed-conifer stand. For Prod J 2007;57:59-69.

[14] Tolosana E, Laina R, Martínez F, Martin M, Ambrosio Y. Manual técnico para el aprovechamiento y elaboración de biomasa forestal. Madrid: Fucovasa; 2009.

[15] Spinelli R, Magagnotti N, Nati C. Options for the mechanized procession of hardwood trees in Mediterraean Forest. Int J For Eng 2009;20:39-44.

[16] Magagnotti N, Pari L, Picchi G, Spinelli R. Energy biomass from the low-investment fully mechanized thinning of hardwood plantations. Biomass Bioenerg 2012;47:195-200.

[17] Cavalli R, Confalonier M, Zamboni R. Approvvigionamento di dendromassa per usi energetici. Sherwood 2003;87:11-6.

[18] Gallis C. Comparative cost estimation for forwarding smallsized beech wood with horses and mini-skidder in northern Greece. For Prod J 2004;54:84.

[19] Magagnotti N. Re-engineering firewood extraction in traditional Mediterranean coppice stands. Ecol Eng 2012;38:45-50.

[20] Zimbalatti G, Proto AR. Cable logging opportunities for firewood in Calabrian forests. Biosyst Eng 2009;102:63-8.

[21] Spinelli R, Magagnotti N, Lombardini C. Performance, capability and costs of small-scale cable yarding technology. Small-scale For 2010;9:123-35.

[22] Cañellas I. Growth response to thinning in Quercus pyrenaica Willd. coppice stands in Spanish central mountain. Ann For Sci 2004;61:243-50.
[23] Ruiz-Peinado Gertrudix R. Biomass models to estimate carbon stocks for hardwood tree species. For Syst 2012;21:42-52.

[24] Ter-Mikaelian MT, Korzukhin MD. Biomass equations for sixty-five North American tree species. For Ecol Manage 1997;97:1-24.

[25] Jenkins J, Jennifer C, Chojnacky D, Heath L, Birdsey A. Comprehensive database of diameter-based biomass regressions for North American tree species 2004. NE-319: 45

[26] Magagnotti N, Spinelli R. Good practice guidelines for biomass production studies. Cost Action FP0902 2012;1:52.

[27] Ambrosio Y, Tolosana E. Estudios de tiempos y rendimientos en los trabajos forestales. El programa Kronos. Revista Montes 2007;87:14-6.

[28] Ackerman P, Lyons J, Eliasson L, George H, Grulois S, Jong A. Equipment costing model. A business model 2011. p. 1-24. Cost Action FP0902.

[29] Rapp M, Santa Regina I, Rico M, Gallego HA. Biomass, nutrient content, litterfall and nutrient return to the soil in Mediterranean oak forests. For Ecol Manage 1999;119:39-49.

[30] Santa Regina I. Biomass estimation and nutrient pools in four Quercus pyrenaica in Sierra de Gata Mountains, Salamanca, Spain. For Ecol Manage 2000;132:127-41.

[31] Ozolinčius R, Buožytė R, Varnagirytė-Kabašinskienè I. Wood ash and nitrogen influence on ground vegetation cover and chemical composition. Biomass Bioenerg 2007;31:710-6.

[32] Solla-Gullón F, Taboada M, Rodríguez-Soalleiro R, Merino A. Respuesta inicial del aporte de cenizas de biomasa arbórea en el estado nutricional de una plantación joven de Pinus radiata D. Don. Invest Agrar: Sist Recur For 2004;13:281-93.

[33] González I. Tablas ponderales para la estimación de la biomasa de rebollo (Quercus pyrenaica Willd.) en la provincia de León 1988. p. 56.

[34] Ovaskainen H, Palander T, Jauhiainen M, Lehtimaki J, Tikkanen L, Nurmi J. Productivity of Energywood harvesting Chain in different stand conditions of Early thinnings. Baltic For 2008;14:149-54.

[35] Nakagawa M, Hayashi N, Narushima T. Effect of tree size on time of each work element and processing productivity using an excavator-based single-grip harvester or processor at a landing. J For Res 2010;15:226-33.

[36] Laitila J, Asikainen A, Nuutinen J. Forwarding of whole trees after manual and mechanized felling bunching in precommercial thinnings. Int J For Eng 2007;18:29-39.

[37] Lindblad J, Äijälä O, Koistinen A. Woodfuel measuring-guide book to Finnish practical applications 2010. p. 1-10.

[38] Spinelli R, Magagnotti N. A tool for productivity and cost forecasting of decentralised wood chipping. For Pol Econ 2010;12:194-8.

[39] Ambrosio Y. Modelos de tiempos, rendimientos y costes de las operaciones semimecanizadas de aprovechamientos de claras de masas de Pinus sylvestris L; 2003. 